\title{
Antimicrobial resistant gene prevalence in soils due to animal manure deposition and long-term pasture management
}

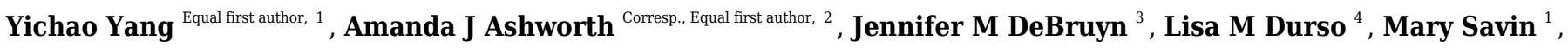 \\ Kim Cook ${ }^{5}$, Philip A Moore, Jr. ${ }^{2}$, Phillip R Owens ${ }^{6}$ \\ 1 Department of Crop, Soil, and Environmental Sciences, University of Arkansas at Fayetteville, Fayetteville, Arkansas, United States \\ 2 Poultry Production and Product Safety Research Unit, United States Department of Agriculture, Agricultural Research Service, Fayetteville, Arkansas, \\ United States \\ 3 Department of Biosystems Engineering \& Soil Science, University of Tennessee - Knoxville, Knoxville, Tennessee, United States \\ 4 Agroecosystem Management Research Unit, United States Department of Agriculture, Agricultural Research Service, Lincoln, Nebraska, United States \\ 5 United States Department of Agriculture, Agriculture Research Service, Beltsville, Maryland, United States \\ 6 Dale Bumpers Small Farms Research Center, United States Department of Agriculture, Agricultural Research Service, Booneville, Arkansas, United \\ States \\ Corresponding Author: Amanda J Ashworth \\ Email address: Amanda.Ashworth@usda.gov
}

PROJECT PLAN The persistence of antimicrobial resistant (AMR) genes in the soilenvironment is a concern, yet practices that mitigate AMR are poorly understood, especially in grasslands. Animal manures are widely deposited on grasslands, which are the largest agricultural land-use in the United States. These nutrient-rich manures may contain AMR genes. The aim of this study was to enumerate AMR genes in grassland soils following 14-years of poultry litter and cattle manure deposition and evaluate if best management practices [rotationally grazed with a riparian (RBR) area and a fenced riparian buffer strip (RBS), which excluded cattle grazing and poultry litter applications] relative to standard pasture management [continuously grazed (CG) and hayed $(\mathrm{H})$ ] systems minimize the presence and amount of AMR genes. Quantitative PCR (Q-PCR) was performed to enumerate four AMR genes (ermB, sull, intll, and $\left.b / a_{c t x-m-32}\right)$ in soil, cattle manure, and poultry litter environments. Six soil samples were additionally subjected to metagenomic sequencing and resistance genes were identified from assembled sequences. Following 14-years of continuous management, ermB, sull, and intll genes in soil were highest $(P<0.05)$ in samples collected long-term continuous grazing (relative to conservation best management practices), suggesting overgrazing and continuous cattle manure deposition may increase AMR gene presence. In general, AMR gene prevalence increased downslope, suggesting potential lateral movement and accumulation based on landscape position. Poultry litter had lower abundance of AMR genes (ermB, sull, and intll) relative to cattle manure. Long-term applications of poultry litter increased the abundance of sull and intll genes in soil $(P<0.05)$. Similarly, metagenomic shotgun sequencing 
revealed a greater total number of AMR genes under long-term CG, while fewer AMR genes were found in $\mathrm{H}$ (no cattle manure) and RBS (no animal manure or poultry litter). Results indicate long-term conservation pasture management practices (e.g. RBS and RBR) and select animal manure (poultry litter inputs) may minimize the presence and abundance of AMR genes in grassland soils. 


\section{Antimicrobial Resistant Gene Prevalence in Soils due to Animal Manure Deposition and Long-term Pasture Management}

Yichao Yang ${ }^{1}$, Amanda J. Ashworth ${ }^{2}$, Jennifer M. DeBruyn ${ }^{3}$, Lisa Durso ${ }^{4}$, Mary Savin ${ }^{1}$, Kimberly Cook ${ }^{5}$, Philip A. Moore, Jr. ${ }^{2}$, and Phillip Owens ${ }^{6}$

${ }^{1}$ Department of Crop, Soil, and Environmental Sciences, University of Arkansas at Fayetteville, Fayetteville, Arkansas, United States;

${ }^{2}$ Poultry Production and Product Safety Research Unit, United States Department of Agriculture, Agricultural Research Service, Fayetteville, Arkansas, United States *corresponding author, Amanda.Ashworth@usda.gov

${ }^{3}$ University of Tennessee - Knoxville, Department of Biosystems Engineering \& Soil Science, Knoxville, Tennessee, United States;

${ }^{4}$ Agroecosystem Management Research Unit, United States Department of Agriculture, Agricultural Research Service, Lincoln, Nebraska, United States;

${ }^{5}$ United States Department of Agriculture, Agriculture Research Service, Beltsville, Maryland, United States;

${ }^{6}$ Dale Bumpers Small Farms Research Center, United States Department of Agriculture, Agricultural Research Service, Booneville, Arkansas, United States.

Keywords: best management practices; cattle manure; poultry litter; microbial abundance.

Abbreviations: AMR, Antimicrobial resistance; RBS, riparian buffer strip; PERMANOVA, permutational analysis of variance; ANOVA, analysis of variance; $\mathrm{CG}$, continuously grazed; $\mathrm{H}$, hayed system; RBR, rotational grazing with a fenced riparian buffer; Q-PCR, quantitativepolymerase chain reaction; ermB, erythromycin resistance gene; sull, sulfonamide resistance gene; intlI, integrase gene; and $b l a_{c t x-m-32}, \beta$-Lactams resistance gene; MLS, macrolides, lincosamides, and streptrogramin (A and B). 


\section{Abstract}

38 The persistence of antimicrobial resistant (AMR) genes in the soil-environment is a concern, yet

39 practices that mitigate AMR are poorly understood, especially in grasslands. Animal manures are

40 widely deposited on grasslands, which are the largest agricultural land-use in the United States.

41 These nutrient-rich manures may contain AMR genes. The aim of this study was to enumerate

42 AMR genes in grassland soils following 14-years of poultry litter and cattle manure deposition

43 and evaluate if best management practices [rotationally grazed with a riparian (RBR) area and a

44 fenced riparian buffer strip (RBS), which excluded cattle grazing and poultry litter applications]

45 relative to standard pasture management [continuously grazed $(\mathrm{CG})$ and hayed $(\mathrm{H})$ ] systems

46 minimize the presence and amount of AMR genes. Quantitative PCR (Q-PCR) was performed to

47 enumerate four AMR genes (ermB, sulI, intlI, and $\left.b l a_{c t x-m-32}\right)$ in soil, cattle manure, and poultry

48 litter environments. Six soil samples were additionally subjected to metagenomic sequencing and

49 resistance genes were identified from assembled sequences. Following 14-years of continuous

50 management, ermB, sulI, and intlI genes in soil were highest $(P<0.05)$ in samples collected long-

51 term continuous grazing (relative to conservation best management practices), suggesting

52 overgrazing and continuous cattle manure deposition may increase AMR gene presence. In

53 general, AMR gene prevalence increased downslope, suggesting potential lateral movement and

54 accumulation based on landscape position. Poultry litter had lower abundance of AMR genes

55 (ermB, sulI, and intlI) relative to cattle manure. Long-term applications of poultry litter increased

56 the abundance of sulI and intlI genes in soil $(P<0.05)$. Similarly, metagenomic shotgun

57 sequencing revealed a greater total number of AMR genes under long-term CG, while fewer

58 AMR genes were found in $\mathrm{H}$ (no cattle manure) and RBS (no animal manure or poultry litter).

59 Results indicate long-term conservation pasture management practices (e.g. RBS and RBR) and 
60 select animal manure (poultry litter inputs) may minimize the presence and abundance of AMR

61 genes in grassland soils.

63

\section{Introduction}

Veterinary pharmaceutical usage is a fundamental component of conventional poultry and bovine production for treating microbial infections and increasing weight gains (Collignon et al., 2009). Repeated use of antibiotics during food-animal production may provide selection pressure for the evolutionary phenomenon known as antimicrobial resistance (AMR). Genes encoding resistance to antimicrobials and antibiotics, which can also naturally be found in many bacteria, can be transferred between organisms via horizontal gene transfer (Juhas, 2015). Agricultural practices influence the prevalence and occurrence of AMR genes in soils. For example, soils amended with cattle manure not treated with antibiotics contained higher abundance of $\beta$-lactam resistant bacteria than soils with inorganic fertilizer inputs (Udikovic-Kolica et al., 2014). In another study, soil applications of swine manure increased erythromycin resistance gene abundance and remained high for a decade post-application (Scott et al., 2018). However, AMR genes occur naturally(Durso et al., 2012); for example, Cadena et al. (2018) identified tetracycline and sulfonamide resistant genes in organic farms without routine antibiotic usage.

There is recent interest in monitoring the dissemination of AMR genes into the environment, particularly those directly relevant to human and animal health, as consumers and producers are increasingly concerned about antibiotic resistance in food systems (Durso et al., 2012). One goal of sustainable agriculture is to close nutrient cycles by applying animal manures to neighboring cropping systems. Additionally, depending on antibiotic properties, large quantities of undegraded antibiotics exit animals to manures, including poultry litter (a combination of 
83 bedding material and excreta); for example, up to $90 \%$ of sulfonamides and $25-75 \%$ of

84 tetracyclines may be excreted into manure as the parent compound (Kulshrestha et al., 2004;

85 Thiele-Bruhn et al., 2004). From manure, antibiotics, genes encoding AMR, and microbes may

86 be transferred to soil (Cook et al., 2014; Heuer et al., 2011; Zhang et al., 2017; He et al., 2014).

87 Therefore, cattle manure and poultry litter applications, which are valuable sources of nutrients

88 such as N, P, and potassium (K), may also be a pathway for AMR bacteria and genes into the

89 environment (Yang et al., 2019a).

90 The ability of pasture management practices (i.e., filter strips and rotational grazing) to

91 reduce AMR gene presence, prevalence, and movement to soils is largely unknown. Our

92 previous work indicated that continuously grazed systems increased soil microbial community

93 richness and diversity owing to greater organic animal inputs (Yang et al., 2019b), which

94 suggests manure increases microbiome diversity and improves soil health. However, animal

95 manure may also be a source for AMR genes. Therefore, the current work aims to understand the

96 impacts of pasture management on AMR bacteria and gene presence. This study focused on

97 quantifying four AMR associated genes [i.e., erythromycin resistance gene (erm $B)$, sulfonamide

98 resistance gene $(s u l l)$, integrase gene $($ intll $)$, and $\beta$-lactam resistance gene $\left.\left(b l a_{c t x-m-32}\right)\right]$ present in

99 pasture soil, cattle manure, and poultry broiler litter using Q-PCR in an effort to balance human,

100 animal, and environmental priorities. These four genes are useful for understanding the ecology

101 and biology of agricultural AMR genes in soil and manure systems (Durso et al., 2012). We

102 additionally applied metagenomic sequencing to reveal the suite of resistance genes in the soil

103 community and to evaluate best management practices that may reduce the presence of AMR

104 genes from manure and poultry litter applications to the soil. 


\section{Materials and Methods}

107 Experimental Design

108 In 2004, a field study was initiated by Pilon et al. (2017a; 2017b; 2018) at the USDA-ARS

109 Unit in Booneville, Arkansas to evaluate how pasture management affects water quality. Nine

110 watersheds (average slope of 8\%) were constructed on Enders and Leadvale silt loams. Each

111 watershed had a total area of 0.14 ha, with the dominant grass species being bermudagrass

112 (Cynodon dactylon L.).

113 Briefly, three grazing strategies were implemented from 2004-2017 with three replications,

114 including: continuously grazed $(\mathrm{CG})$, hayed $(\mathrm{H})$, and rotationally grazed with an ungrazed,

115 fenced riparian strip (RBR; Yang et al., 2019) (Fig. 1). The CG treatment was consistently

116 grazed by one to two calves during the year (Pilon et al., 2017a). The H treatment was hayed

117 three times annually (April, June, and October) to a height of $10 \mathrm{~cm}$ (no cattle in these

118 watersheds). The RBR system is considered a best management strategy and was rotationally

119 grazed based on forage height (Pilon et al., 2017a; 2017b; 2018). Calves (three) were placed in

120 rotationally grazed watersheds based on forage height (when heights were 20 to $25 \mathrm{~cm}$ ) and

121 removed (10 to $15 \mathrm{~cm}$ ) (Yang et al., 2019). Each watershed was divided into 3 zones

122 (perpendicular to slope) given that topography widely affects the microbial biogeography (Yang

123 et al., 2019). Landscape positions corresponded to upper slope (zone 1), mid-slope (2), and

124 downslope positions (3), whereas the RBR represented zone 4 (Yang et al., 2019). The riparian

125 buffer strip (RBS) and served as the nested control. The length of the 3 zones in CG and H was

$12657 \mathrm{~m}$ and the length of the 3 zones in RBR was $42.75 \mathrm{~m}$. Broiler litter was surface applied at 5.6

$127 \mathrm{Mg}$ dry matter per ha in April-May of each year per watershed (excluding the RBS). All poultry

128 litter rates were equivalent on an aerial basis (Yang et al., 2019). Broiler litter was obtained 
129 annually from a nearby commercial broiler farm. The RBR watersheds had a fenced off, riparian

130 area containing four tree species at the base of each watershed (Pilon et al., 2017a; Yang et al.,

131 2019). The RBS (zone 4) was not grazed and did not receive poultry litter applications (Fig. 1).

132 Watersheds received no other human or animal inputs during the project duration.

133 Sample collection

134 Soil sampling occurred once pre-poultry litter application (April) and other post-litter 135 application (July; within 2 months following poultry litter land application) in 2016 and 2017

136 (four sampling dates total). Soils were manually collected to a $0-15 \mathrm{~cm}$ depth (6 randomly

137 selected samples in zone centers and composited to one sample), with three replicates total

138 ( $\mathrm{n}=120$ total). One sample per zone was collected, transported in a cooler, and later stored at -

$13980^{\circ} \mathrm{C}$ for DNA extraction (Yang et al., 2019). Sampling equipment was sterilized between

140 watersheds with $70 \%$ ethanol $\left(\mathrm{C}_{2} \mathrm{H}_{6} \mathrm{O}\right)$.

141 Prior to poultry litter application on each watershed in 2018 and 2019, a central sample was 142 collected from broiler house windrow piles $(n=6$ total $)$. In tandem, for treatments receiving

143 cattle (Angus crosses) manure inputs (i.e., CG and RBR), two fresh manure samples were

144 collected post deposition (within $24 \mathrm{~h}$ ) per watershed ( $\mathrm{n}=12$ total). Right before DNA

145 extraction, fresh, composited samples (soil, manure, and poultry litter samples) were weighed

146 and dried at $70^{\circ} \mathrm{C}$ for $48 \mathrm{~h}$ and reweighed to determine gravimetric moisture content.

147 Detection and analysis of four antibiotic resistance associated genes following long-term

148 management using $Q-P C R$

149 Soil, cattle manure, and poultry litter samples were homogenized and $0.25 \mathrm{mg}$ of each

150 sample was used for DNA extraction. Isolation and purification of DNA from samples (soil: $\mathrm{n}=$

151 120; cattle manure: $\mathrm{n}=12$; poultry litter: $\mathrm{n}=6$ ) was conducted with the PowerSoil ${ }^{\circledR}$ DNA 
152 Isolation Kit (MoBio Laboratories Inc., Cat. 12888-100) according to the manufacturer's

153 protocol. Extracted DNA were quantified using Quant-iT ${ }^{\mathrm{TM}}$ PicoGreen $^{\mathrm{TM}}$ dsDNA Assay Kit

154 (ThermoFisher Scientific, Cat. P7589) and used directly in quantitative Q-PCR. All 120, 6, and

15512 soil, cattle manure, and poultry litter DNA samples, respectively, were subjected to Q-PCR

156 for detection of four genes associated with AMR as described in the clinical isolates, which

157 included ermB (Florez et al., 2014), sulI (Barraud et al., 2010), intlI (Pei et al., 2006), and bla $a_{c t x-}$

158 m-32 (Szczepanowski et al., 2009), using previously published primers (Table 1). Each PCR

159 amplification was performed in triplicate. The positive control (named gBlock2 4G with 16S

160 ermB Florez 1-18-17) is an 808bp double stranded synthetic gBlocks ${ }^{\circledR}$ gene fragment

161 synthesized by Integrated DNA technologies, lnc. (Blazejewski et al., 2019). Standard curves

162 consisted of a serial dilution (known gene fragment copy numbers ranging from $1.15 \times 10^{5}$ to

$1631.15 \times 10^{11}$ copies per $\left.5 \mu 1\right)$.

164 Amplifications were performed in a QuantStudio ${ }^{\mathrm{TM}} 3$ Real-Time PCR system (ThermoFisher

165 Scientific, Cat. A28137). Each $20 \mu \mathrm{L}$ Q-PCR reaction included $5 \mu \mathrm{L}$ of extracted DNA

166 (approximately $100 \mathrm{ng}$ ) or standard, $10 \mu \mathrm{L}$ of SYBR Green PCR Master Mix, and $100 \mathrm{mM}$ of

167 each primer. As a negative control, all sets of primers were tested with sterile water as the

168 template; and all of them were below the threshold. Each reaction was technically replicated for

169 three times per extracted sample DNA and standard DNA, resulting in an average cycle

170 threshold $(\mathrm{Ct})$ value used to estimate the initial quantity. Cycling conditions including annealing

171 temperature specific for each gene are provided in Table 1. The amplification efficiency was

172 between $92 \%$ and $105 \%$, and the $\mathrm{R}^{2}$ value was above 0.98 . Baseline and threshold calculations

173 were performed using QuantStudio ${ }^{\circledR}$ Design \& Analysis software. Amplified products were

174 visualized on a 1\% agarose gel with an ethidium bromide stain. The quantities of gene copy 
175 numbers were then determined using standard curves. Gene copy abundances were then

176 normalized per gram dry weight of soil, cattle manure, and poultry litter after measuring the

177 moisture content of each sample. Finally, the gene copy numbers per gram dry weight were

178 transformed into $\log 10$ values for further statistical analysis as they were not normally

179 distributed (Ganger et al., 2017).

180 To detect significant differences for fixed effects (pasture management, sample collection

181 timing, and zone) an analysis of variance (ANOVA) was conducted on log transformed data

182 using JMP software $\left[\mathrm{JMP}{ }^{\circledR} 12\right.$ (SAS Institute, 2007)] with replicate as a random effect.

183 Probability values less than 0.05 were considered significant and pairwise posthoc comparisons

184 were made using Tukey's Honestly Significant Difference test. Samples below detection limit

185 were excluded in the analysis.

186 Metagenomic sequencing and data analysis

187 To evaluate long-term effects of pasture management on AMR genes, metagenomic 188 sequencing was applied for 6 soil samples [post-application zone 3, CG; post-application zone 3

$189 \mathrm{H}$; post-application zone 3 RBR, post-application zone 3, RBS all replication 1; and, post-

190 application zone 3 RBR, post-application zone 3, RBS replication 2) ]. Sequencing libraries were

191 prepared according to the Illumina Miseq sample preparation guide. Metagenomic sequencing

192 was performed using Miseq Reagent Kits v2 with paired-end 2 x 250 bp reads on the MiSeq

193 platform (University of Tennessee Genomics Core; Knoxville, TN). Raw data were uploaded to

194 NCBI with the accession number of SAMN 14783573-14783584. Read trimming and assembly

195 were performed according to Tyson (2015). Genomes were annotated using the AmrPlusPlus

196 pipeline (Lakin et al., 2017). All samples resulted in a total of $5.19 \mathrm{~Gb}$ of sequence data.

197 Trimmomatic was used for removal of low-quality bases and sequences (Lakin et al., 2017). 
198 Reads classified as host genome (Bos taurus and Gallus gallus) were removed from further

199 analysis. The adapter contamination and low-quality reads were also removed. The database

200 'MEGARes' has been integrated inside the pipeline and used for identification of AMR genes.

201 AMR genes with a gene fraction (i.e. proportion of nucleotides that aligned with at least one

202 query read) of $>85 \%$ coverage across all alignments were considered to be positively identified

203 in a sample (Noyes et al., 2016a). The minimum length of a read was 150 and the mean Phred

204 score was above 30. The AMR gene analysis was carried out using the Resistome Analyzer tool

205 (https://github.com/cdeanj/resistomeanalyzer) (Lakin et al., 2017). Utilizing this tool, three

206 annotation levels were produced, which include gene-level (sequencing-level), mechanism-level,

207 and class-level counts.

208

209 Results

210 Distribution of four AMR associated genes in soil based on pasture management, landscape

211 position, and sampling time

212 Soil ermB gene abundance varied among treatments (CG, H, RBR, and RBS) and zones (1, 2,

213 3, and 4) $(P<0.05)$ (Fig. 2A), although, sample collection time (pre- or post-poultry litter

214 applications; $P>0.05$ ) had no impact on the abundance of ermB gene (Table 2; Fig. 2B). There

215 was an interaction effect from pasture management and zone on the abundance of erm $B$ genes.

216 Across pasture management, the highest abundance of ermB gene was found in the CG treatment

217 ( $\mu$ log gene copies per gram dry weight soil $=3.03)$, followed by $\mathrm{H}(2.86$ gene copies per gram

218 dry weight soil), RBR (2.72 gene copies per gram dry weight soil) and RBS (0.73 gene copies

219 per gram dry weight soil) (Fig. 2A). Compared with RBS, CG increased the abundance of ermB

220 by $2.3 \log , \mathrm{H}$ increased the abundance of $\operatorname{ermB}$ by $2.13 \mathrm{log}$, and RB increased the abundance of 
$221 \mathrm{ermB}$ by $1.99 \log$. Among zones, the greatest abundance of ermB occurred in zone 3 ( $\mu \log$ gene

222 copy numbers per dry weight $=2.92)$, followed by zone 2 ( 2.91 gene copy numbers per dry

223 weight), zone 1 (2.78 gene copy numbers per dry weight), and zone 4 ( 0.73 gene copy numbers

224 per dry weight) (Fig. 2C). Compared with zone 4, zone 3 increased the abundance of ermB by

$2252.19 \log$, zone 2 increased the abundance of ermB by $2.18 \log$, zone 1 increased the abundance of

$226 \operatorname{ermB}$ by $2.05 \log$. However, no abundance differences occurred between pre and post poultry

227 litter applications ( $\mu$ log gene copy numbers per gram dry weight in pre-sampling time $=2.86 \mathrm{vs}$.

228 post-sampling time $=2.45)($ Fig. $2 \mathrm{~B})$.

229 There were differences in the abundance of the gene sulI among all three factors, including

230 treatments, sampling time, and zone $(P<0.05)($ Fig. 2$)$. For pasture management, the highest

231 abundance was found under CG ( $\mu$ log gene copy numbers per dry weight=4.83), followed by

232 RB (4.46), H (4.42), and RBS (2.93) (Fig. 2A). Among zones, the greatest abundance was found

233 in zone $2(\mu \log$ gene copy numbers per gram dry weight $=4.66)$, followed by zone $1(4.66)$, zone

2343 (4.38), and zone 4 (2.93) (Fig. 2C). Differences in abundance were identified between pre and

235 post poultry litter sampling time, with a higher abundance of sulI occurring post poultry litter

236 applications (Fig. 2B; log gene copy numbers per gram dry weight=4.77 vs. pre-sampling=

237 4.03). There was also an interaction for pasture management by zone for the sulI gene.

238 Similar to sull, there were differences in the intlI gene based on all three factors $(P<0.05)$

239 (Fig. 2). Based on the influence from pasture management, ANOVA tests indicated that greatest

240 abundances were found under long-term CG ( $\mu$ log gene copy numbers per gram dry

241 weight=3.41), followed by H (3.11), and RB (3.07). The least abundance of AMR genes were

242 found in RBS (1.54) (Fig. 2A), with greatest intlI gene occurring in zone 2 ( $\mu$ log gene copy

243 numbers per gram dry weight $=3.22$ ), then zone 1 (3.19), zone 3 (3.18), and zone 4 (1.54) (Fig. 
244 2C). The abundance of the intlI gene differed between pre and post sampling, with higher

245 abundances in soil samples collected after poultry litter application $(\mu \log$ gene copy numbers

246 per dry weight in post-sampling time $=3.79$ vs. pre-sampling $=2.28)($ Fig. $2 \mathrm{~B})$. There was pasture

247 management by zone, pasture management by timing, and zone by timing interactions for the 248 abundance of the intlI gene.

249 After finding differences following long-term pasture management on the abundance of these 250 three AMR associated genes, further analyses were conducted to illustrate the abundance of each 251 AMR associated gene based on the pasture management treatments. Among these 93 samples, $252 \mathrm{ermB}$ was found in $77 \%$ of samples, while only one amplification was from the RBS ( $8 \%$ of RBS 253 was amplified), and 92 samples were from all treatment groups ( $85 \%$ of treatment samples were 254 amplified). Among these 92 positive samples from treatment groups, it included $78 \%$ of RBR 255 samples, $92 \%$ of CG, $86 \%$ of $\mathrm{H}$, and $8 \%$ of RBS. Gene sulI was detected in 119 out of 120 256 samples (99\%) and intlI were detected in all samples (100\%), while $b l a_{c t t-m-32}$ was not found in 257 any soils except two (following poultry litter application in zone 2 of CG in 2016 and one in zone 3 of the $\mathrm{H}$ treatment in 2017). The gene $b l a_{c t-m-32}$ was not included in the Table 2 and Fig. 259 2, due to no amplification.

Abundance of these three AMR associated genes indicates there are greater abundances of each AMR associated genes found in $\mathrm{CG}$, RBR and $\mathrm{H}$, relative to RBS $(P<0.05$; Fig. 2A). For

262 the RBS (no grazing or direct manure or poultry litter deposition), there was no amplification of 263 ermB gene from all samples during 2016, while only one sample included an ermB gene in 2017.

264 Overall, post poultry litter applications, soil samples had greater abundance of sulI and intlI

265 genes than pre-application soils. In Fig. 2C, the abundance of these three AMR associated genes

266 were split out based on zones. Based on the factor of zone, differences were observed in these 
267 three AMR associated genes, ermB, sulI, and intlI $(P<0.05)$. Among these four zones, the lowest

268 abundance was found in zone 4 (no cattle manure or poultry litter) among these three genes.

269

270

271

272

273

274

275

276

277

278

279

280

281

282

283

284

285

286

287

288

\section{Distribution of four AMR associated genes in cattle manure and poultry litter}

Considering continuous annual applications of cattle and poultry manure were applied to soils (over 14-years), authors were interested in the presence of the four AMR associated genes and whether the abundance varied between soils with manure applied from the two sources. Results from Q-PCR indicated these three AMR associated genes (ermB, sulI and intll) were found in all poultry litter samples collected in 2019; however, the abundance of AMR-associated genes from poultry litter in the year of 2018 were below the detection threshold. The gene of $b l a_{c t x-m-32}$ was not found in any poultry litter and cattle manure samples (Table 3). Based on the ANOVA, there were differences in these three AMR associated genes between cattle manure and poultry litter, with greater abundances occurring in cattle manure than poultry litter $(53,95$, and $100 \%$ greater mean value of gene copies per gram dry weight for ermB, sulI, and intlI in cattle manure than poultry litter, respectively) $(P<0.05)$ (Table 3$)$. The impact of sampling year on the abundance of ermB gene was found $(P<0.05)$, with greater abundance in 2019 compared to 2018 .

\section{Prevalence of antimicrobial resistance genes based on pasture management}

Purified genomic DNA extracts from six soil samples were chosen for shotgun metagenomic sequencing to evaluate the impact of pasture management on AMR genes. Several unique AMR genes per treatment were identified (Table 4). The number of unique AMR genes, mechanisms, and classes identified in $\mathrm{H}$ was lower than other treatments, including the RBS.

Resistome Analyzer in AmrPlusPlus pipeline provided four levels of annotation database hierarchy, at levels of gene, group, mechanism, and class. In each level, the counts of each gene 
289 can be found in the output file (Supplementary Table 1). These identified resistance genes were

290 listed from the greatest numbers of hits (multi-drug resistance class) to least (Bacitracin). Based

291 on the database of MEGARes 2.0, the multi-drug resistance was defined as genes and

292 mechanisms that cause resistance to two or more different antibiotic classes. Typically, such

293 mechanisms involve active extrusion of antibiotic molecules from the bacterial cell or

294 mechanisms that prevent the drug from reaching its target (Lakin et al., 2017). The class of

295 multi-drug resistance genes were identified as greater than other resistance gene classes among

296 all treatments and RBS (Supplementary Table 1). Fig. 3 shows relative proportion of hits in each

297 class level by treatments. Overall, the greatest (i.e., 33\%) of identified genes from the multi-drug

298 resistance class were found in the CG treatment, followed by RBR watersheds (28\%), the RBS

299 (24\%), and H watersheds (15\%).

300

301 Discussion

302 Distribution of four AMR associated genes in soils based on pasture management, landscape

303 position, and sampling time

304 AMR is a naturally occurring phenomenon, and soils are considered a reservoir for AMR

305 genes (Kieser et al., 2000). Overall, pasture management (CG, H, RBR, and RBS) had an effect

306 on three AMR-associated genes, ermB, sulI, and intlI $(P<0.05)$. Greater abundance of these three

307 AMR associated gene in soils were detected in treatments receiving either long-term poultry

308 litter or cattle manure inputs (CG, $\mathrm{H}$, and $\mathrm{RBR}$ ), while lower AMR gene abundances were found

309 in RBS, which was not grazed and did not receive direct poultry litter applications. This

310 indicates these three AMR-associated genes were potentially transmitted via animal feces and

311 may be transferred into the soil through animal movement and land application. This finding was 
312 consistent with other studies which found that the repeated application of animal manure

313 increased antibiotic resistance genes in agricultural soils (Luby et al., 2016; Kim et al., 2017).

314 The sample collection timing (pre or post poultry litter application) had an effect on two

315 AMR-associated genes, sulI and intlI $(P<0.05)$. A greater abundance of these two genes in soils

316 were detected in samples collected after poultry litter applications (July) rather than before

317 poultry litter applications (April). The abundance of sull and intlI genes increased after poultry

318 litter applications, indicating poultry litter may include sulI and intlI genes and increase the

319 abundance of sulI and intlI genes in soils. This result is consistent with previous work using $16 \mathrm{~S}$

320 rRNA sequencing, which found that poultry litter timing greatly influenced soil community

321 structure and gene abundance (Yang et al., 2019; Ashworth et al., 2017). However, poultry litter

322 application timing did not influence the other two genes, ermB and $b l a_{c t x-m-32}$. Another study

323 pointed out that the concentration of AMR genes [sulI, intlI, tetracycline (tetW), and

324 streptomycin $(\operatorname{strp} B)]$ in soil following poultry litter fertilization were greater following 21 to

325133 days after application (Cook et al., 2014). These data suggest poultry litter applications may

326 increase the abundance and persistence of AMR-associated genes within the soil.

327 The factor of zone had an effect on the abundance of these three AMR-associated genes

328 (ermB, sulI, and intlI) within the soil $(P<0.05)$, with higher abundance in zone 1 , zone 2 , and

329 zone 3, and lowest abundance in zone 4. This result suggests that animal manure played an

330 important role in enhancing the abundance of AMR associated genes into the soil. We also found

331 that genes of sulI and intlI existed in the soil of zone 4, even though there was no input from

332 animal manure in this region, thus indicating that these two AMR-associated genes may be

333 inherent to the soil. Since some AMR genes were found in non-agricultural and un-grazed native

334 soils, they were considered as a natural part of pristine habitats (Durso et al., 2012 and 2016). 
335 This result showcases the importance of evaluating baseline and background levels of AMR

336 genes when investigating the impact of human input in the occurrence of AMR bacteria and

337 genes (Durso et al., 2012).

338 The gene $b l a_{c t x-m-32}$ was not detected in most soil samples, indicating that $b l a_{c t x-m-32}$ was not

339 prevalent in the locations sampled. Having information on AMR presence in soils is valuable, as

340 previous observations have shown antibiotics may impact the soil microbial community

341 composition and structure, which will ultimately influence ecosystem-scale processes by

342 maintaining these AMR bacteria and genes (Gutierrez et al., 2010; Toth et al., 2011).

343 Distribution of four AMR associated genes in cattle manure and poultry litter

344 Three AMR associated genes (ermB, sull, and intll) were more abundant in cattle manure

345 compared to poultry litter. Although, previous studies derived the opposite conclusion. Wang et

346 al. (2016) indicated that the ermB gene levels in poultry litter were greater than that of cattle

347 manure. Cattle antibiotics and drugs were used over the course of this experiment

348 (Supplementary Table 2); though, without the information of antibiotics used during poultry

349 production, it is difficult to ascertain that AMR associated genes were related to specific animal

350 management practices. Regardless of where these AMR associated genes originate, we should

351 pay attention to the abundance and movement of these resistance genes, such as ermB, because

352 macrolides are a major broad-spectrum antibiotic for human use and play an important role in

353 controlling Gram-positive bacterium infection clinically (Kanoh and Rubin, 2010). We also

354 detected three AMR associated genes (ermB, sulI, and intlI) in poultry litter in 2019, but not in

355 2018. These differing results between years indicates gene presence varied annually perhaps due

356 to differences in environmental or animal management factors. There was a difference identified

357 from the ermB gene between 2018 and 2019 with a greater abundance in 2019 and less 
358 abundance in 2018. However, it is difficult to ascertain whether this difference was caused by

359 animal inputs without the drug usage information on cattle and poultry in these two years.

360 Prevalence of antimicrobial resistance genes from shotgun sequencing following pasture

361 management

362 Quantifying the prevalence of specific AMR genes may use culture-independent methods,

363 such as Q-PCR, as well as metagenomic sequencing (Agga et al., 2015; Durso et al., 2012).

364 Metagenomic sequencing allows for the tracking of AMR genes and identification of

365 transmission of AMR from animals to the environment (Oniciuc et al., 2018). Recent studies

366 using functional metagenomic screening of cattle feces reported the maximum number of AMR

367 genes detected per animal was 26 (Wichmann et al., 2014), which was much lower than the

368 number identified from soil samples in this experiment. The identified AMR genes have broad

369 biological activities and might have other functions, rather than only AMR gene encoding. Take

370 the efflux pumps as an example, as it is usually one of the largest AMR mechanisms; however,

371 clinical and laboratory studies suggest efflux pumps have a role in virulence and the adaptive

372 responses as well (Du et al., 2018).

373 The multi-drug resistance gene classes were conferred to phenicol, lincosamide,

374 oxazolidinones (linezolid), pleuromutilin, and streptogramin (Noyes et al., 2016a). However, in

375 the RBS (down slope, but no direct animal input from cattle manure and poultry litter), multi-

376 drug resistance genes were identified. Therefore, it is possible some AMR genes were not from

377 anthropogenic sources, but rather a naturally occurring community component (Bhullar et al.,

378 2012), or that surface runoff moved AMR genes downslope. Similarly, Rothrock et al. (2016)

379 indicated antibiotic resistant Listeria and Salmonella spp. occur in all-natural, antibiotic-free,

380 pasture-raised broiler flocks. Future work is needed evaluating the potential movement of AMR 
381 genes via surface water runoff (Jacobs et al., 2019). Durso et al. (2016) also characterized native

382 Nebraska prairie soils that had not been affected by human or food-animal waste products and

383 found that all prairies contained tetracycline and cefotaxime-resistant bacteria, and $48 \%$ of soil

384 bacteria were resistant to two or more antibiotics. Bhullar et al. (2012) also reported that AMR

385 bacteria and genes can be found from in pristine soil environments that have not been exposed to

386 human antibiotic use, from which, some strains were resistant to a wide range of different

387 commercially available antibiotics. Cadena et al. (2018) also reported that tetracycline and

388 sulfonamide antibiotic resistance genes can be identified from organic farming operations.

389 Based on the MEGARes database, the macrolides, lincosamides, and streptogramins (MLS)

390 A and B were classified as MLS drugs (Lakin et al., 2016), and were identified in soil samples in

391 the present experiment. The MLS class, according to Tenson et al. (2003), "contains structurally

392 different but functionally similar drugs acting by binding to the 50 S ribosomal subunit and

393 blocking the path where nascent peptides exit the ribosome." Noyes et al. (2016b) reported that

394 MLS resistance genes can be detected in both cattle and calves and were equally abundant

395 between dairy and beef herds. Overall, the resistance classes of metronidazole and thiostrepton

396 were identified only from the RBR group, and bacitracin resistance genes were detected only in

397 the CG treatment. Due to the limitation of the sample number for metagenomic sequencing,

398 further studies are necessary to estimate the influence of animal inputs on AMR genes.

\section{Conclusions}

401 Results characterized the abundance of AMR genes following 14-years of pasture

402 management using Q-PCR and metagenomics sequencing. The quantitative amplification

403 method suggests increased abundances in three AMR-associated genes (ermB, sull, and intll) in 
404 soils may be due to long-term cattle manure deposition and poultry litter applications to a lesser

405 extent. Using shotgun metagenomic sequencing, we identified the relative abundance of AMR

406 genes were greater in $\mathrm{CG}$ than $\mathrm{H}$, indicating that cattle manure deposition may serve as an AMR

407 source to the environment (relative to poultry litter applications). Additionally, conservation

408 pasture management practices such as rotationally grazing and filter strips decreased soil AMR

409 gene presence, as the unfertilized fenced riparian buffer strip displayed $31.58 \%$ lower gene

410 abundance (relative to the CG treatment, based on the AMR gene numbers identified through

411 metagenomic sequencing). While the metagenomic approach has important applications in

412 investigating AMR genes, it is noteworthy that metagenomic methods do have limitations and

413 results may be affected by incomplete resistome databases. Overall, results illustrate that cattle

414 manure inputs may influence AMR abundance in soils and conservation management may

415 minimize AMR gene presence in the environment.

416

417

418

419

420

421

422

423

424

Peer] reviewing PDF | (2020:05:48736:4:0:CHECK 25 Sep 2020) 


\section{Figure Captions}

426 Figure 1. Diagram of the experimental set-up (nine watersheds total, consistently managed from 427 2004-2018). CG (continuously grazed), H (hayed), and RBR (rotationally grazed with a fenced 428 off riparian buffer). All areas received annual poultry litter applications (except for the RBS area 429 which received neither poultry litter nor cattle manure inputs). Only the CG and RBR received 430 cattle manure. Each watershed was divided into 3 zones[ (perpendicular to slope, whereas the 431 RBR consisted of three zones plus the RBS (zone 4)]. [Soil samples, $n=120$; cattle manure, $n=$ 432 12; poultry litter, $\mathrm{n}=6$; and, shotgun sequencing, soil, $\mathrm{n}=6]$.

433 Figure 2. Mean abundances of three AMR associated genes, ermB, sulI and intlI amplified from 434 soil genomic DNA samples based on (A) pasture management, (B) sampling time (pre and post 435 poultry litter application) and (C) zone (zone 1, zone 2, zone 3, and zone 4). CG (continuously 436 grazed), H (hayed), and RBR (rotationally grazed with a fenced off riparian buffer). Error bars

437 represent standard errors. The connecting letters indicates a significant difference at an alpha 438 level of 0.05 .

439 Figure 3. The relative proportion of AMR resistance gene classes in soils from different pasture 440 management systems. Six soil genomic DNA extracts were sequenced by using shotgun 441 metagenomic sequencing to evaluate the impact of pasture management on antibiotic resistant 442 genes. Each AMR gene classes was normalized to $100 \%$ for identifying the percentage of 443 resistance genes from each treatment in each class of resistance gene. Pasture treatments include:

444 CG (continuously grazed), H (hayed), and RBR (rotationally grazed with a fenced off riparian

445 buffer). The RBR treatment consists of an additional fenced riparian buffer strip (RBS) that was 446 ungrazed (no cattle manure) without direct poultry litter applications. Grey=CG, Yellow=H, 447 Blue $=$ RBR, and Orange $=$ RBS. 
448

449

450

451

452

453

454

455

456

457

458

459

460

461

462

463

464

465

466

467

468

469

470

471

472

473

474

475

476

477

478

479

480

481

482

483

484

485

486

487

488

489

490

491

492

493

\section{References}

Ashworth, AJ, JM DeBruyn, FL Allen, MA Radiosevich, and PR Owens. 2017. Microbial community structure is affected by cropping sequences and poultry litter under long-term notillage. Soil Biol. and Biochem.114: 210-219.

Agga GE, Arthur TM, Durso LM, Harhay DM, and Schmidt JW. 2015. Antibiotic-resistant bacterial populations and Antibiotic resistance genes obtained from environments impacted by livestock and municipal waste. PLoS ONE 10: e0132586.

Barraud O, Baclet MC, Denis F, and Ploy MC. 2010. Quantitative multiplex real-time PCR for detecting class 1, 2, and 3 integrons. J. Antimicrob. Chemother. 65: 1642-1645.

Bhullar K, Waglechner N, Pawlowski A, Koteva K, Banks ED, Johnston MD, Barton HA, Wright GD. 2012. Antibiotic resistance is prevalent in an isolated cave microbiome. PLoS ONE 7: e34953.

Blazejewski T, Ho HI, Wang HH. 2019. Synthetic sequence entanglement augments stability and containment of genetic information in cells. Science 365: 595-598.

Cadena M, Durso LM, Miller DN, Waldrip HM, Castleberry BL, Drijber RA, and Wortmann C. 2018. Tetracycline and sulfonamide antibiotic resistance genes in soils from Nebraska organic farming operations. Front. Microbiol. 9: 1283.

Caporaso JG, Lauber CL, Walters WA, Berg-Lyons D, Lozupone CA, Turnbaugh PJ, Fierer N, and Knight R. 2011. Global patterns of 16S rRNA diversity at a depth of millions of sequences per sample. Proc. Natl. Acad. Sci. USA 108 (Suppl 1): 4516-4522.

Collignon P, Powers JH, Chiller TM, Aidara-Kane A, Aarestrup AFM. 2009. World health organization ranking of antibiotics according to their importance in human medicine: a critical step for developing risk management strategies for the use of antibiotics in food production animals. Clin. Infect. Dis. 49: 132-141.

Cook KL, Netthisinghe AMP, and Gilfillen RA. 2014. Detection of pathogens, indicators, and antibiotic resistance genes after land application of poultry litter. J. Environ. Qual. 43: 15461558.

Du D, Wang-Kan X, Neuberger A, Van-Veen HW, Pos KM, Piddock LJV, and Luisi BF. 2018. Multidrug efflux pumps: structure, function and regulation. Nat. Rev. Microbiol. 16: 523-539.

Durso LM, Miller DN, Wienhold BJ. 2012. Distribution and quantification of antibiotic resistant genes and bacteria across agricultural and non-agricultural metagenomes. PLOS ONE 7: e48325.

Durso LM, Wedin DA, Gilley JE, Miller DN, and Marx DB. 2016. Assessment of selected antibiotic resistances in ungrazed native Nebraska prairie soils. J. Environ. Qual. 45: 454462.

Florez AB, Alegria A, Rossi F, Delgado S, Felis GE, Torriani S, and Mayo B. 2014. Molecular identification and quantification of tetracycline and erythrocycline resistance genes in Spanish and Italian retail cheeses. BioMed. Res. Intern.746859: 1-10.

Forsberg KJ, Reyes A, Wang B, Selleck EM, Sommer MO, Dantas G. 2012. The shared antibiotic resistome of soil bacteria and human pathogens. Science 337: 1107-11.

Ganger MT, Dietz GD, Ewing SJ. 2017. A common base method for analysis of qPCR data and the application of simple blocking in qPCR experiments. BMC Bioinformatics 18: 534.

Gutierrez IR, Watanabe N, Harter T, Glaser B, Radke M. 2010. Effect of sulfonamide antibiotics on microbial diversity and activity in a Californian Mollic Haploxeralf. J. Soils Sediments 10: 537-544. 
494

495

496

497

498

499

500

501

502

503

504

505

506

507

508

509

510

511

512

513

514

515

516

517

518

519

520

521

522

523

524

525

526

527

528

529

530

531

532

533

534

535

536

537

He LY, Liu YS, Su HC, Zhao JL, Liu SS. Chen J, Wang-Rong L, and Guang-Guo Y. 2014. Dissemination of antibiotic resistance genes in representative broiler feedlots environments: identification of indicator ARGs and correlations with environmental variables. Environ. Sci. and Tech. 48: 13120-13129.

Heuer H, Schmitt H, and Smalla K. 2011. Antibiotic resistance gene spread due to manure application on agricultural fields. Current Opinion in Microbiol. 14: 236-243.

Jacobs K, Wind L, Krometis LA, Hession WC, and Pruden, A. 2019. Fecal indicator bacteria and antibiotic resistance genes in storm runoff from dairy manure and compost-amended vegetable plots. J. Environ. Qual. 48: 1038-1046.

Juhas M. 2015. Horizontal gene transfer in human pathogens. Crit. Rev. Microbiol. 41: 101-108.

Kanoh S, Rubin BK. 2010. Mechanisms of action and clinical application of macrolides as immunomodulatory medications. Clin. Microbiol. Rev. 23: 590-615.

Kieser T, Bibb Mervyn J, Buttner Mark J, Chater Keith F, and Hopwood DA. 2000. Practical streptomyces genetics. John Innes Foundation, Colney.

Kim JH, Kuppusamy S, Kim SY, Kim SC, Kim HT, and Lee YB. 2017. Occurrence of sulfonamide class of antibiotics resistance in Korean paddy soils under long-term fertilization practices. J. Soils Sediments 17: 1618-1625.

Kozich JJ, Westcott SL, Baxter NT, Highlander SK, Schloss PD. 2013. Development of a dualindex sequencing strategy and curation pipeline for analyzing amplicon sequence data on the MiSeq Illumina sequencing platform. Applied Environ. and Microbiol. 79: 5112-5120.

Kulshrestha P, Giese RF, and Aga DS. 2004. Investigating the molecular interactions of oxytetracycline in clay and organic matter: insights on factors affecting its mobility in soil. Environ. Sci. \& Tech. 38: 4097-4105.

Lakin SM, Dean C, Noyes NR, Dettenwanger A, AS Ross, Doster E, Rovira P, Abdo Z, Jones KL, Ruiz J, Belk KE, Morley PS, and Boucher C. 2017. MEGARes: an antibiotic resistance database for high throughput sequencing. Nucleic Acids Res. 45: D574-D580.

Luby EM, Moorman TB, and Soupir ML. 2016. Fate and transport of tylosin-resistant bacteria and macrolide resistance genes in artificially drained agricultural fields receiving swine manure. Sci. of the Total Environ. 550: 1126-1133.

Noyes NR, Yang X, Linke LM, Magnuson RJ, Dettenwanger A, Cook S, Geornaras I, Woerner DE, Gow SP, McAllister TA, Yang H, Ruiz J, Jones KL, Boucher CA, Morley PS, and Belk KE. 2016a. Resistome diversity in cattle and the environment decreases during beef production. ELife 5: e13195.

Noyes NR, Yang X, Linke LM, Magnuson RJ, Cook SR, Zaheer R, H Yang, Woerner DR, Geornaras I, McArt JA, Gow SP, Ruiz J, Jones KL, Boucher CA, McAllister TA, Belk KE, and Morleya PS. 2016b. Characterization of the resistome in manure, soil and wastewater from dairy and beef production systems. Sci. Rep. 6: 24645.

Oniciuc EA, Likotrafiti E, Alvarez-Molina A, Prieto M, Santos JA, Alvarez-Ordóñez A. 2018. The present and future of whole genome sequencing (WGS) and whole metagenome sequencing (WMS) for surveillance of antibiotic resistant microorganisms and antibiotic resistance genes across the food chain. Genes 9: 268.

Pei R, Kim S, Carlson KH, and Pruden A. 2006. Effect of river landscape on the sediment concentrations of antibiotics and corresponding antibiotic resistance genes (ARG). Water Res. 40: 2427-2435. 
538

539

540

541

542

543

544

545

546

547

548

549

550

551

552

553

554

555

556

557

558

559

560

561

562

563

564

565

566

567

568

569

570

571

572

573

574

575

576

577

578

579

580

581

582

Pilon C, Moore PA, Jr, Pote DH, Pennington JH, Martin JW, Brauer DK, Raper RL, Dabney SM, Lee J. 2017a. Long-term effects of grazing management and buffer strips on soil erosion from pastures. J. Environ. Qual. 46: 364-372.

Pilon C, Moore PA, Jr, Pote DH, Martin JW, DeLaune PB. 2017b. Effects of grazing management and buffer strips on metal runoff from pastures fertilized with poultry litter. $J$. Environ. Qual. 46: 402-410.

Pilon C, Moore PA, Jr, Pote DH, Martin JW, Owens PR, Ashworth AJ, Miller DM, DeLaune PB. 2018. Grazing management and buffer strip impact on nitrogen runoff from pastures fertilized with poultry litter. J. Environ. Qual. 48: 297-304.

R Core Team. 2012. R: a language and environment for statistical computing. Vienna: R Foundation for Statistical Computing.

Rothrock MJ, Hiett KL, Guard JY, Jackson CR. 2016. Antibiotic resistance patterns of major zoonotic pathogens from all-natural, antibiotic-free, pasture-raised broiler flocks in the Southeastern United States. J. Environ. Qual. 45: 593-603.

SAS Institute, Inc. 2014. SAS/STAT 9.4 user's guide. Cary: SAS Institute.

Scott A, Tien Y, Drury CF, Daniel Reynolds W, Topp E. 2018. Enrichment of antibiotic resistance genes in soil receiving composts derived from swine manure, yard wastes, or food wastes, and evidence for multiyear persistence of swine Clostridium spp. Canadian J.of Microbiol. 64: 201-208.

Skurnik D, Le Menac'h A, Zurakowski D, Mazel D, Courvalin P, Denamur E, Andremont A, Ruimy R. 2005. Integron-associated antibiotic resistance and phylogenetic grouping of Escherichia coli isolates from healthy subjects free of recent antibiotic exposure. Antimicrob. Agents Chemother. 49: 3062-3065.

Szczepanowski R, Linke B, Krahn I, Gartemann K, Gutzkow T, EicherW, Puhler A, Schlueter A. 2009. Detection of 140 clinically relevant antibiotic-resistance genes in the plasmid metagenome of wastewater treatment plant bacteria showing reduced susceptibility to selected antibiotics. Microbiol. 155: 2306-2319.

Tenson T, Lovmar M, Ehrenberg M. 2003. The mechanism of action of macrolides, lincosamides and streptogramin B reveals the nascent peptide exit path in the ribosome. J. Mol. Biol. 330: 1005-1014.

Toth JD, Feng YC, Dou ZX. 2011. Veterinary antibiotics at environmentally relevant concentrations inhibit soil iron reduction and nitrification. Soil Biol. Biochem. 43: 24702472.

Thiele-Bruhn S, Seibicke T, Schulten HR, and Leinweber P. 2004. Sorption of sulfonamide pharmaceutical antibiotics on whole soils and particle-size fractions. J. Environ. Qual. 33: 1331-1342.

Tyson GH, McDermott PF, Li C, Chen Y, Tadesse DA, Mukherjee S, Bodeis-Jones S, Kabera C, Gaines SA, Loneragan GH, Edrington TS, Torrence M, Harhay DM, Zhao S. 2015. Whole genome sequencing accurately predicts antibioitic resistance in Escherichia coli. $J$ Antimicrob. Chemother. 70: 2763-2769.

Udikovic-Kolic N, Wichmann F, Broderick NA, and Handelsman J. 2014. Bloom of resident antibiotic-resistant bacteria in soil following manure fertilization. Proc. Natl. Acad. Sci. U.S.A. 111: 15202-15207.

USDA. 2009. Dairy 2007, Part V: Changes in Dairy Cattle Health and Management Practices in the United States, 1996-2007 USDA: APHIS:VS, CEAH. Fort Collins, CO \# 519.0709. 
583 Wang N, Guo X, Yan Z, Wang W, Chen B, Ge F, Ye B. 2016. A comprehensive analysis on spread and distribution characteristic of antibiotic resistance genes in livestock farms of southeastern China. PLOS ONE. 11: e0156889.

Wichmann F, Udikovic-Kolic N, Andrew S, and Handelsman J. 2014. Diverse antibiotic resistance genes in dairy cow manure. MBio 5: e01017.

Yang Y, Ashworth AJ, Willett C, Cook K, Upadhyay A, Owens PR, Ricke SC, DeBruyn JM, Moore PA Jr. 2019a. Review of antibiotic resistance, ecology, dissemination, and mitigation in U.S. broiler poultry systems. Front. Microbiol. 10: 2639.

Yang Y, Ashworth AJ, DeBruyn JM, Willett C, Durso LM, Cook K, Moore PA Jr, Owens PR. 2019b. Soil bacterial biodiversity is driven by long-term pasture management, poultry litter, and cattle manure inputs. PeerJ. 7: e7839.

Zhang YJ, Hu HW, Gou M, Wang JT, Chen D, He JZ. 2017. Temporal succession of soil antibiotic resistance genes following application of swine, cattle and poultry manures spiked with or without antibiotics. Environ. Poll. 231: 1621-1632. 


\section{Figure 1}

Schematic representation of the experimental set-up.

Figure 1. Schematic representation of the experimental set-up. Randomized complete block design with three replications (nine watersheds total) from 2004-2018. All areas have received annual poultry litter applications (except for the RBS area). The RBS received neither poultry litter nor cattle manure inputs. CG and RBR received cattle manure. Each watershed was divided, perpendicular to the slope into three zones [corresponding to shoulder (A), upper backslope (B), and lower backslope (C) positions], whereas the RBR consisted of these three zones plus the RBS (zone 4). [Soil samples, $n=120$; cattle manure, $n=12$; poultry litter, $n=6$; and, shotgun sequencing, soil, $n=6$ ]. 
RBD with 3 replications, 9 watersheds. All with annual poultry litter

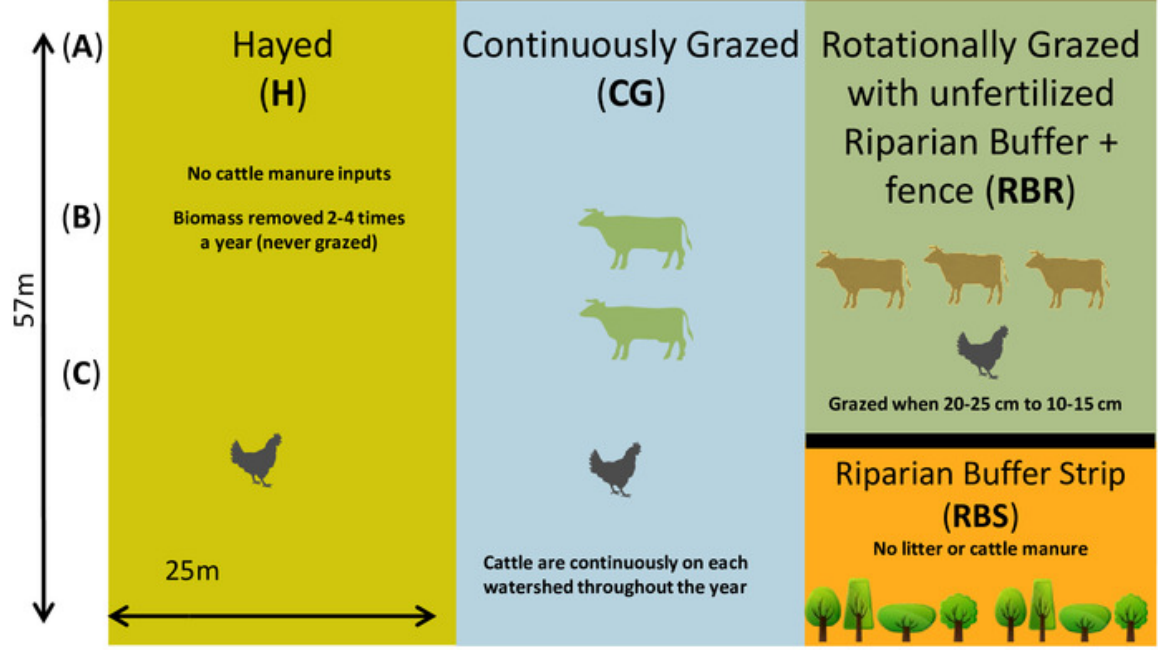




\section{Figure 2}

Table 3. ANOVA results illustrating the abundance of three AMR associated genes in cattle manure and poultry litter.

Table 3. ANOVA results illustrating the differences of the abundance of three AMR associated genes were impacted by the single factor, animals (cattle manure vs. poultry litter), and year (2018 vs. 2019), and interaction between these two factors in cattle manure and poultry litter samples collected from 2018-2019. 

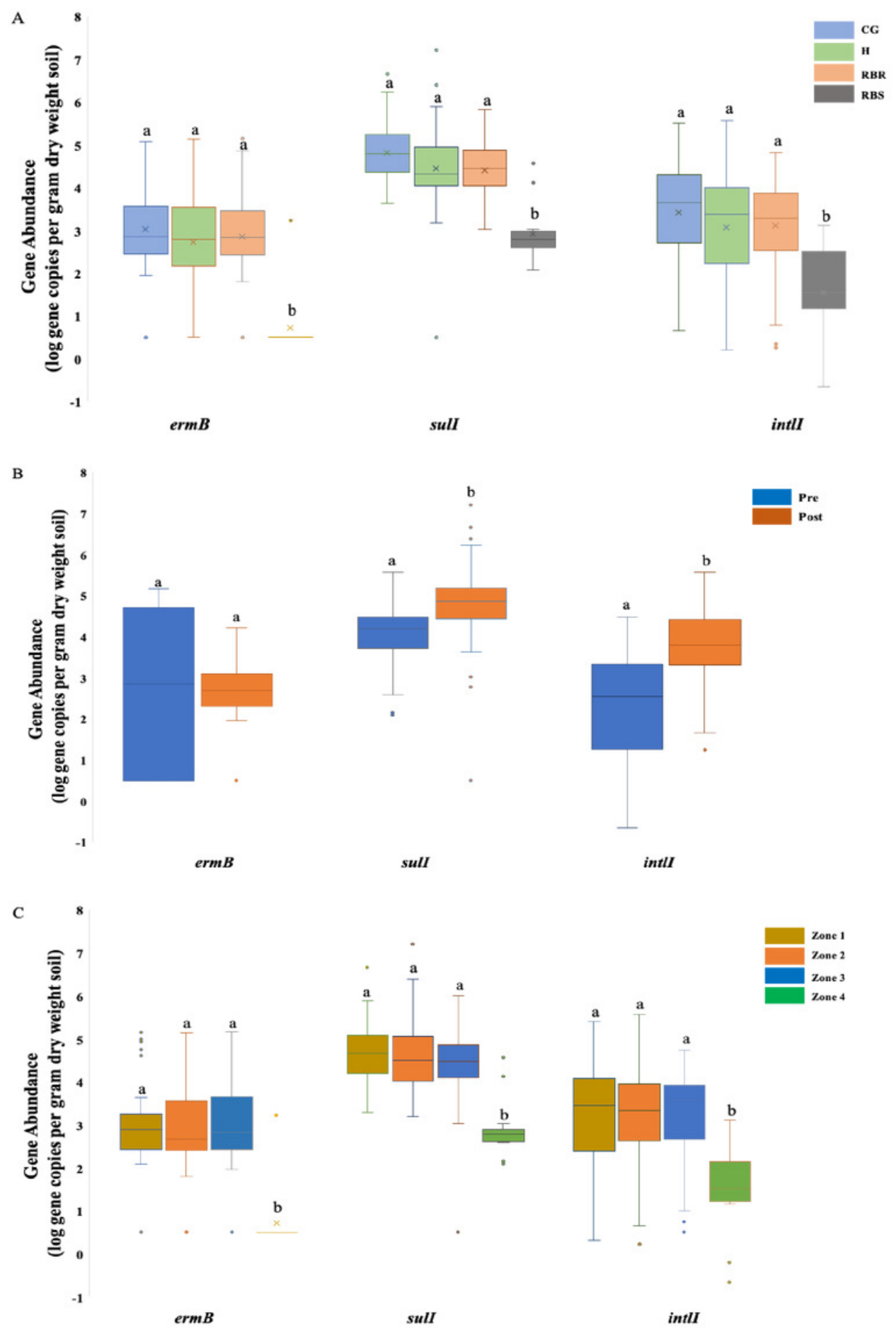


\section{Figure 3}

Relative proportion of AMR genes in grassland soils based on pasture managment.

Figure 3. The relative proportion of AMR resistance gene classes in soils from different pasture management systems. Six soil genomic DNA extracts were sequenced by using shotgun metagenomic sequencing to evaluate the impact of pasture management on antibiotic resistant genes. Each AMR gene classes was normalized to $100 \%$ for identifying the percentage of resistance genes from each treatment (CG, H, RBR, and RBS) in each class of resistance gene. Pasture management includes continuously grazed $(\mathrm{CG})$, hayed $(\mathrm{H})$, and rotational grazed with a fenced riparian buffer (RBR). The RBR treatment consists of an additional fenced riparian buffer strip (RBS) that was a non-grazed zone without direct addition of poultry litter or grazing that had trees. Grey $=\mathrm{CG}$, Yellow $=\mathrm{H}, \mathrm{Blue}=\mathrm{RBR}$, and Orange $=$ RBS . 


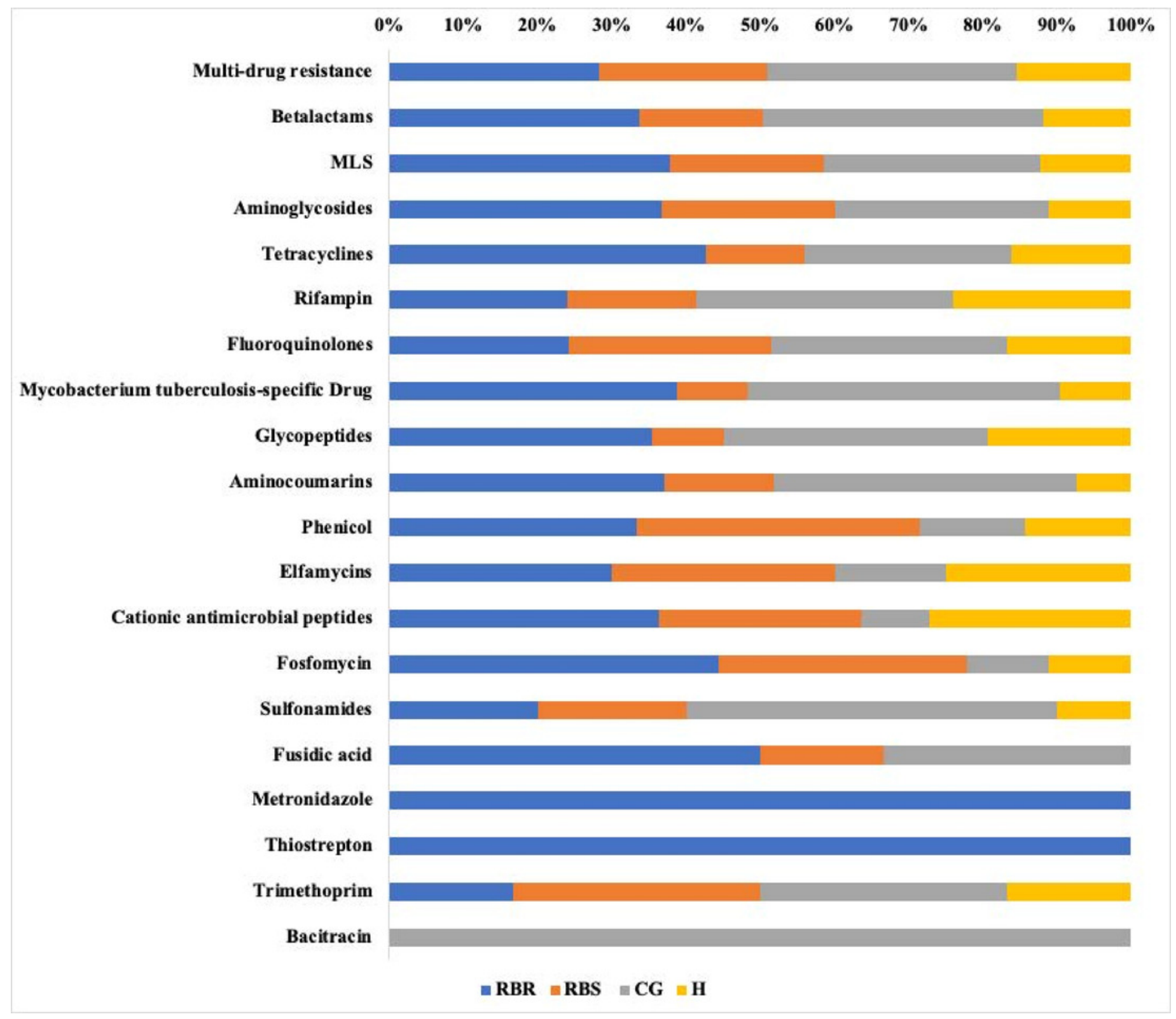




\section{Table 1 (on next page)}

Q-PCR primers used in this project.

Table 1. Sequence and properties of the Q-PCR primers used in this project. 
1 Table 1. Sequence and properties of the Q-PCR primers used in this project.

\begin{tabular}{|c|c|c|c|c|c|}
\hline Target gene & Application/Primer & Sequence ( $\left.5^{\prime}-3^{\prime}\right)$ & $\begin{array}{c}\text { Annealing } \\
\text { temperature } \\
\left({ }^{\circ} \mathrm{C}\right)\end{array}$ & $\begin{array}{l}\text { Amplicon } \\
\text { size (bp) }\end{array}$ & Reference \\
\hline blactx-m-32 & $\begin{array}{l}\text { ctx-m-32FWD } \\
\text { ctx-m-32RVS }\end{array}$ & $\begin{array}{l}\text { CGTCACGCTGTTGTTAGGAA } \\
\text { CGCTCATCAGCACGATAAAG }\end{array}$ & 63 & 156 & $\begin{array}{l}\text { (Szczepanowski et al., } \\
\text { 2009) }\end{array}$ \\
\hline ermB & $\begin{array}{l}\text { ermB-QPCR-F-Florez } \\
\text { ermB-QPCR-R-Florez }\end{array}$ & $\begin{array}{l}\text { GGATTCTACAAGCGTACCTTGGA } \\
\text { AATCGAGACTTGAGTGTGCAAGAG }\end{array}$ & 60 & 69 & (Florez et al., 2014), \\
\hline sull & $\begin{array}{l}\text { sul I FW } \\
\text { sul I RVS }\end{array}$ & $\begin{array}{l}\text { CGCACCGGAAACATCGCTGCAC } \\
\text { TGAAGTTCCGCCGCAAGGCTCG }\end{array}$ & 65 & 163 & (Barraud et al., 2010) \\
\hline intlI & $\begin{array}{l}\text { intI1LC5 FW } \\
\text { intI1LC1 RV }\end{array}$ & $\begin{array}{l}\text { GATCGGTCGAATGCGTGT } \\
\text { GCCTTGATGTTACCCGAGAG }\end{array}$ & 55 & 196 & (Pei et al., 2006) \\
\hline
\end{tabular}

2

3

4

5

6

7

8

9

10

11

12

13

14

15

16

17

18

19

20

21

22

23

24

25

26

Peer] reviewing PDF | (2020:05:48736:4:0:CHECK 25 Sep 2020) 


\section{Table 2 (on next page)}

Differences in abundance of three AMR genes

Table 2. ANOVA results testing for differences in abundance of three AMR genes (log gene copies per gram dry weight soil) in soil samples influenced by main factors, pasture management (CG, H, RBR and RBS), sampling time (pre and post) and zone (zone 1, zone 2, zone 3 , and zone 4), as well as the interactions between two main factors (pasture $x$ timing, pasture $x$ zone, and timing $x$ zone) and three main factors (pasture $x$ timing $x$ zone) at Booneville, AR from 2016-2017. 
1 Table 2. ANOVA results testing for differences in abundance of three AMR genes (log gene

2 copies per gram dry weight soil) in soil samples influenced by main factors, pasture management

3 (CG, H, RBR and RBS), sampling time (pre and post) and zone (zone 1, zone 2, zone 3, and

4 zone 4), as well as the interactions between two main factors (pasture $\mathrm{x}$ timing, pasture $\mathrm{x}$ zone,

5 and timing $\mathrm{x}$ zone) and three main factors (pasture $\mathrm{x}$ timing $\mathrm{x}$ zone) at Booneville, AR from

$6 \quad 2016-2017$.

\begin{tabular}{|c|c|c|c|c|}
\hline Parameter & Factor & df & F-value & $P$-value \\
\hline \multirow[t]{7}{*}{ ermB } & Pasture Management & 3 & 10.399 & $<0.0001^{*}$ \\
\hline & Time & 1 & 2.464 & 0.119 \\
\hline & Zone & 3 & 10.088 & $<0.0001 *$ \\
\hline & Pasture $\mathrm{x}$ Time & 3 & 1.299 & 0.277 \\
\hline & Pasture x Zone & 9 & 3.813 & $<0.001^{*}$ \\
\hline & Zone $\mathrm{x}$ Time & 3 & 1.245 & 0.297 \\
\hline & Pasture $\mathrm{x}$ Zone $\mathrm{x}$ Time & 9 & 0.366 & 0.949 \\
\hline \multirow[t]{7}{*}{ sulI } & Pasture Management & 3 & 16.188 & $<0.001^{*}$ \\
\hline & Time & 1 & 20.499 & $<0.001 *$ \\
\hline & Zone & 3 & 14.917 & $<0.001^{*}$ \\
\hline & Pasture $\mathrm{x}$ Time & 3 & 1.035 & 0.380 \\
\hline & Pasture $\mathrm{x}$ Zone & 9 & 5.851 & $<0.001^{*}$ \\
\hline & Zone $\mathrm{x}$ Time & 3 & 1.640 & 0.184 \\
\hline & Pasture $\mathrm{x}$ Zone $\mathrm{x}$ Time & 9 & 1.532 & 0.145 \\
\hline \multirow[t]{6}{*}{ intlI } & Pasture Management & 3 & 6.891 & $<0.001^{*}$ \\
\hline & Time & 1 & 56.512 & $<0.001^{*}$ \\
\hline & Zone & 3 & 6.268 & $<0.001^{*}$ \\
\hline & Pasture $\mathrm{x}$ Time & 3 & 3.093 & $<0.05^{*}$ \\
\hline & Pasture $\mathrm{x}$ Zone & 9 & 2.256 & $<0.05^{*}$ \\
\hline & Zone $\mathrm{x}$ Time & 3 & 3.058 & $<0.05^{*}$ \\
\hline
\end{tabular}




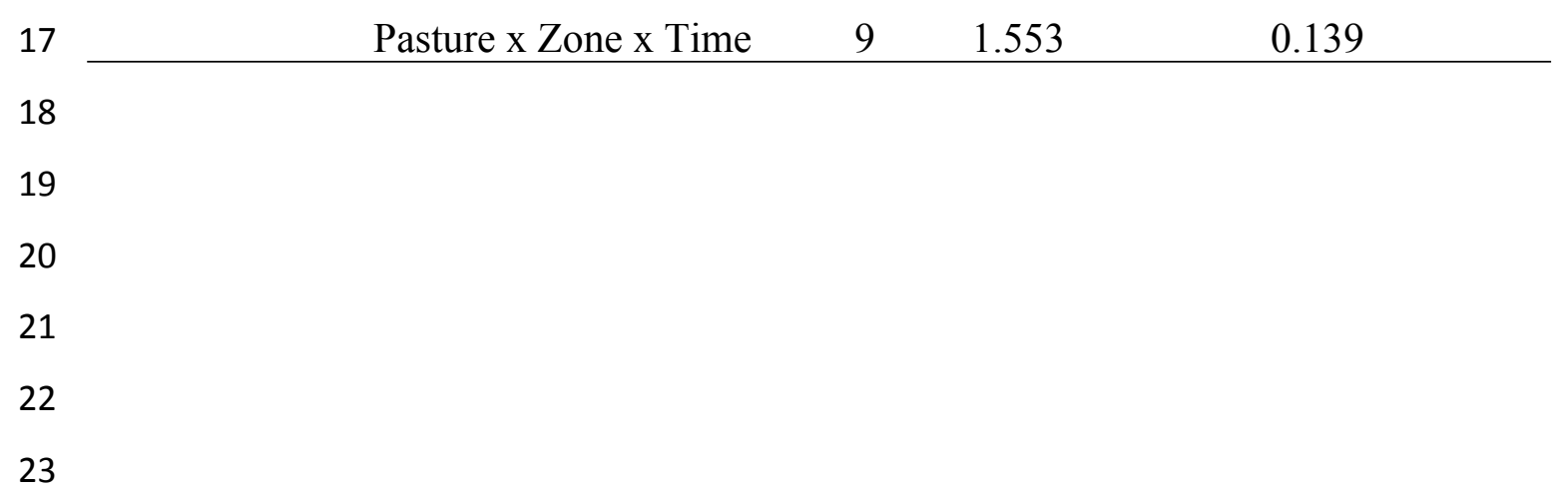




\section{Table 3 (on next page)}

Table 3. ANOVA of the abundance of three AMR associated genes in cattle manure and poultry litter.

Table 3. ANOVA results illustrating the differences of the abundance of three AMR associated genes were impacted by the single factor, animals (cattle manure vs. poultry litter), and year (2018 vs. 2019), and interaction between these two factors in cattle manure and poultry litter samples collected from 2018-2019. 
1 Table 3. ANOVA results illustrating the differences of the abundance of three AMR associated 2 genes were impacted by the single factor, animals (cattle manure vs. poultry litter), and year 3 (2018 vs. 2019), and interaction between these two factors in cattle manure and poultry litter 4 samples collected from 2018-2019.

\begin{tabular}{|c|c|c|c|c|}
\hline Parameter & Factor & $\begin{array}{l}\text { Quantity per gram } \\
\text { (log gene copies/gram } \\
\text { dry weight manure) } \pm \mathrm{SD}\end{array}$ & $F$-value & P-value \\
\hline \multirow[t]{5}{*}{ ermB } & Animal (cattle manure vs. poultry litter) & Cattle Manure: $4.66 \pm 0.39$ & 6.298 & $0.023 *$ \\
\hline & & Poultry Litter: $2.45 \pm 0.99$ & & \\
\hline & Year (2018 vs. 2019) & 2018: $2.77 \pm 0.64$ & 8.433 & $0.010 *$ \\
\hline & & 2019: $5.08 \pm 0.47$ & & \\
\hline & Animal x Year & & 0.141 & 0.711 \\
\hline \multirow[t]{5}{*}{ sulI } & Animal (cattle manure vs. poultry litter) & Cattle Manure: $4.60 \pm 0.17$ & 6.815 & $0.0189 *$ \\
\hline & & Poultry Litter: $2.40 \pm 1.18$ & & \\
\hline & Year (2018 vs. 2019) & 2018: $3.07 \pm 0.79$ & 3.452 & 0.082 \\
\hline & & 2019: $4.66 \pm 0.34$ & & \\
\hline & Animal x Year & & 3.893 & 0.062 \\
\hline \multirow[t]{4}{*}{ intI } & Animal (cattle manure vs. poultry litter) & Cattle Manure: $4.93 \pm 0.52$ & 29.524 & $0.001 *$ \\
\hline & & Poultry Litter: $0.50 \pm 0.50$ & & \\
\hline & Year (2018 vs. 2019) & 2018: $2.87 \pm 0.94$ & 0.865 & 0.366 \\
\hline & Animal x Year & 2019: $4.04 \pm 0.85$ & 0.461 & 0.505 \\
\hline
\end{tabular}

5

6

7

8 


\section{Table 4 (on next page)}

Resistance genes in three features

Table 4. Resistance genes in three features (gene level, mechanism level, and class level). The number of genes, mechanism and class is the total number of unique AMR gene found without duplication. The gene hits are used as a count of how many times a given gene is found in the data. $n=6$ soil samples [one replication of $C G$ and $H$, with two replications for RBR and the RBS at a consistent landscape position landscape position, and sampling timing (i.e., zone 3 and post poultry litter applications)]. 
1 Table 4. Resistance genes in three features (gene level, mechanism level, and class level). The 2 number of genes, mechanism and class is the total number of unique AMR gene found without 3 duplication. The gene hits are used as a count of how many times a given gene is found in the 4 data. $n=6$ soil samples [one replication of $C G$ and $H$, with two replications for RBR and the 5 RBS at a consistent landscape position landscape position, and sampling timing (i.e., zone 3 and 6 post poultry litter applications)].

\begin{tabular}{lcccc}
\hline & CG & H & RBR & RBS \\
\hline AMR Gene Number & 210 & 105 & 208 & 143 \\
AMR Gene Mechanism Number & 55 & 42 & 53 & 40 \\
AMR Gene Class Number & 18 & 16 & 19 & 17 \\
Hits & 308 & 139 & 312 & 192 \\
\hline
\end{tabular}

7

8 